\title{
Factors Affecting Production of Vanamei Shrimp Pond Farming in Pidie Jaya District-Aceh Province, of Indonesia
}

\author{
Johan Yunus ${ }^{1}$, Ernik Yuliana ${ }^{2}$, and Sri Harijati ${ }^{2}$ \\ ${ }^{1}$ Master of Marine Science Program Students Interested in Management \\ Indonesia Open University \\ ${ }^{2}$ Lecturer at Indonesia Open University \\ Indonesia
}

\begin{abstract}
This study aims to analyze the factors that influence the production results of shrimp pond farming, namely: length of experience in farming, land area, fry stocking density, amount of feed given, number of workers / laborers, capital, harvest time, and installation of mills. The samples in this study were 45 respondents. Analysis technique used for this research is Cobb-Douglass function model. The results of the analysis show that the experience factor has a significant effect on the 100\% confidence level in increasing the production of ponds, both semi-intensively and intensively managed. Statistically at the 95\% confidence level, it turns out that every additional 1 year of experience in Vannamei Shrimp farming activities will result in an increase in production yield of $651 \mathrm{~kg}$. Factors such as the area of arable land, the number of workers employed, the density of fry stocked, the number of pinwheels installed, the amount of bait given, and the amount of capital spent statistically still have little effect on increasing the production of Vannamei Shrimp in Pidie Jaya district so far.
\end{abstract}

Keywords: Business Experience, Land Area, Fry, Feed, Labor, Capital, Mill, Shrimp Production.

\section{INTRODUCTION}

In the implementation of the GBHN, the element of equitable development and its results is always placed as the first element of the development trilogy. For the implementation of the element of equity, the government has set eight equalization lines. Among them include equitable fulfillment of basic needs which includes the fisheries sector. Development in the field of fishery aims to increase yields and quality of production, increase farmers' income and standard of living, expand employment and business opportunities, support industrial development, and increase exports. In an effort to increase production in the fishery sector, the government has made main efforts, namely: intensification, extensification, diversification, and rehabilitation of critical lands, and mangrove forests whose purpose is to increase the income and welfare of farmers and their families. If we explore in depth, it is clear that the fisheries sector plays an important role in the Indonesian economy. This is partly due to: most of Indonesia's population lives and works in the fisheries sector; the contribution of the fishery sector to national income is very large; to meet the basic needs of the people partly from the fishery sector; and fishery products are a very significant source of foreign exchange. the contribution of the fishery sector to national income is very large; to meet the basic needs of the people partly from the fishery sector; and fishery products are a very significant source of foreign exchange. the contribution of the fishery sector to national income is very large; to meet the basic needs of the people partly from the fishery sector; and fishery products are a very significant source of foreign exchange.

The fisheries sector is no less important than other sectors. Therefore, the government designed the fishery sector, among others, to increase production with fishery business productivity in the direction of protein food self-sufficiency in order to improve the nutritional quality of the people; improve the standard of living of fishermen and farmers and expand productive employment opportunities in the fisheries sector.

Brackish water cultivation The Aceh region is one of the largest areas in the territory of the Republic of Indonesia, namely; besides West Java, Central Java, East Java, and South Sulawesi. According to the Fisheries Service Annual Report, the area of brackish water that has become a resource for ponds in Aceh is approximately 42,534.5 ha. Pidie Jaya Regency itself, already has a productive pond area of about $\pm 2,076.20 \mathrm{Ha}$. which stretches along the periphery of $\pm 32.0544 \mathrm{~km}$ of coastline and covers about $2 \%$ of its terrestrial. The coastal area of Pidie Jaya has the potential for pond cultivation because topographically it has a low average percent slope. This situation is appropriate as stated by Djurjani (1998) that land with a slope between $0-1 \%$ makes it 
easier to manage water in ponds so that operational costs are relatively cheaper.Commodities cultivated in ponds in Pidie Jaya Regency currently consist of tiger shrimp, vannamei shrimp, milkfish, shrimp and milkfish, and others. The commodities that are grouped in the miscellaneous class are commodities in small quantities from several types of commodities such as tilapia, tilapia, crabs and so on. The distribution of commodities in each sub-district in Pidie Jaya Regency is different from one another.Of the 2,076.20 ha area in the Pidie Jaya Regency area, 790.00 ha are used for Vannamei Shrimp cultivation. Then from this 790.00 ha 278 of them are processed intensively.

The number of new production per year reached 8,716.66 kg.In fact, according to theory, if the ponds are intensively cultivated with an area of 512 ha, the result should be $278 \times 6,000 \mathrm{~kg} /$ time of harvest =1,468,000 kg/time of harvest.This is of course caused by various factors. For example; labor factor (labor), labor experience and education, working capital factor, fry stocking factor, land area factor, and also what should not be ignored, namely: technology factor. Therefore, pond farming can now be grouped into 3 (three) groups, namely; traditional farming, semi-intensive farming, and modern (intensive) farming. These three farms are highly dependent on technological factors. Especially in this study the technological factor in question is the installation of a windmill in aquaculture.

In 2014, s111 Pidie Jaya pond farmers received business capital in the form of grants and social assistance (Bansos) which were distributed through the local Maritime Affairs and Fisheries Service (DKP). The total APBA funds disbursed are IDR 5,910,442,500. with details namely; social assistance (Bansos) Rp 4,657,625,000, - and the remaining Rp 1,252,817,500 in the form of grants. The handover was carried out symbolically by the Head of DKP Pidie Jaya, Ir Kamaluddin in the local hall. Of the 111 groups that received assistance, as many as 97 of them were recipients of social assistance, while only 14 received grants. Only the aid that was packaged for grants was 14 people whose funds were larger, namely from Rp. 60 million to Rp. 99 million. Meanwhile, social assistance is only Rp. 30 million to Rp. 65 million. The funds are used, among others, for equipment, fry or fish seeds, feed, pond construction, and the like for those who do business in the field of freshwater/brackish water cultivation (Serambi Indonesia, December 30, 2014). Then in March 2016, Pidie Jaya pond farmers also obtained shrimp seed rock fromThe Directorate General of Aquaculture (DJPB) of the Ministry of Marine Affairs and Fisheries through the Ujung Batee Cultivation Fisheries Center (BPBAP), Banda Aceh, totaled 1.6 million fry.

The main purpose of this study was to analyze the factors that influence the production of shrimp pond farming, namely: length of experience in farming, land area, stocking density of fry, amount of feed given, number of labor/labor, capital, harvest time, and pinwheel installation.

\section{LITERATURE REVIEW}

\subsection{Development of Shrimp Cultivation in Indonesia}

Shrimp that are widely cultivated in Indonesia are Vannamei shrimp and tiger shrimp. Windu shrimp are widely cultivated traditionally but are more susceptible to disease and slow growth than Vannamei shrimp. Vannamei shrimp have been successfully cultivated by applying intensive technology as well as traditional or modern traditional, while tiger prawns are still cultivated using simple or traditional technology. Vannamei shrimp is included in household consumption. Vannamei, among others, are more disease resistant, grow faster, are resistant to the environment, and have a shorter maintenance time, an average of 30-120 days per cycle, Vannamei shrimp are also food-efficient (Haliman and Adijaya, 2005).

\subsection{Fisheries Potential in Aceh}

To explore the natural potential that comes from fisheries, it can be divided into two types, namely: marine fisheries and land fisheries. According to the Department of Fisheries, the area of marine fisheries in Aceh is estimated at 56,563 km2 (excluding the 200-mile EEZ area) with a potential source of 110,045 tons mill per year. In 2014 it only reached 90,543.3 tons or 82.28\% of the target. Meanwhile, land fisheries with a large area $\pm 48,908$ ha can only produce 35,514.9 tons. This much yield comes from freshwater cultivation (ponds and rice fields) and brackish water cultivation (ponds).

Brackish water cultivation The Aceh region is one of the largest areas in the territory of the Republic of Indonesia, namely; besides West Java, Central Java, East Java, and South Sulawesi. According to the Fisheries Service Annual Report, the area of brackish water that has become a resource for ponds in Aceh is approximately 42,534.5 ha. At present, the area of ponds that have been operating in the Aceh area.

So when compared between the results obtained and the expectedvery much difference $(8,716.66 \mathrm{~kg}<18,032 \mathrm{~kg})$. This is certainly caused by various factors such as; labor factor (hurry)h), labor experience and education, working capital factor, fry stocking factor, land area factor, and what should not be ignored, namely: technology factor. Therefore, pond farming can now be grouped into 3 (three) groups, namely: traditional farming, semi-intensive farming, and modern (intensive) farming. These three 
International Journal of Research in Social Science and Humanities (IJRSS), Vol. 3 (2), Feb - 2022

farms are highly dependent on technological factors. Especially in this study the technological factor in question is the installation of a windmill in aquaculture.

\subsection{Government Policy Review on Increasing Shrimp Production}

Shrimp is the leading export commodity of Indonesian fishery products. Vannamei shrimp is one of the shrimp that is cultivated in Indonesia and as an export commodity and for the domestic market. The shrimp pond revitalization program launched by the Ministry of Maritime Affairs and Fisheries (KKP) since 2012, has succeeded in significantly increasing shrimp production. To boost national shrimp production, KKP through its revitalization program succeeded in optimizing the pond land by creating a pilot model in the form of 14 farm demonstrations or demonstrations. As a result, national shrimp production as of September 2013 has reached 480 thousand tons. This amount has exceeded the production achievement in 2012 which reached 457600 tons. The pond revitalization program with demfarm has also had an effect on traditional shrimp farmers and the community around the demfarm pond location. Where, ponds that were previously stalled and less productive are now starting to produce. The increase in production is positively correlated with the increase in the area of shrimp farming ponds around the demfarm pond. It was recorded that there was an addition of new pond area which reached 675 ha in 6 locations of demfarm ponds, namely Serang, Tangerang, Karawang, Subang, Indramayu and Cirebon. The addition of aquaculture area will directly improve the welfare of the farmers and fishpond workers. The pond revitalization program is also able to absorb labor both seasonal and permanent workers as many as 130 thousand people (KKP, 2013). The increase in production is positively correlated with the increase in the area of shrimp farming ponds around the demfarm pond. It was recorded that there was an addition of new pond area which reached 675 ha in 6 locations of demfarm ponds, namely Serang, Tangerang, Karawang, Subang, Indramayu and Cirebon. The addition of aquaculture area will directly improve the welfare of the farmers and fishpond workers. The pond revitalization program is also able to absorb labor both seasonal and permanent workers as many as 130 thousand people (KKP, 2013). The increase in production is positively correlated with the increase in the area of shrimp farming ponds around the demfarm pond. It was recorded that there was an addition of new pond area which reached 675 ha in 6 locations of demfarm ponds, namely Serang, Tangerang, Karawang, Subang, Indramayu and Cirebon. The addition of aquaculture area will directly improve the welfare of the farmers and fishpond workers. The pond revitalization program is also able to absorb labor both seasonal and permanent workers as many as 130 thousand people (KKP, 2013). The addition of aquaculture area will directly improve the welfare of the farmers and fishpond workers. The pond revitalization program is also able to absorb labor both seasonal and permanent workers as many as 130 thousand people (KKP, 2013). The addition of aquaculture area will directly improve the welfare of the farmers and fishpond workers. The pond revitalization program is also able to absorb labor both seasonal and permanent workers as many as 130 thousand people (KKP, 2013).

\subsection{Factors Affecting the Success of Vannamei Shrimp Farms}

One of the prerequisites for Vannamei shrimp culture that should not be forgotten is that the inlet water channel and the waste water channel must be separated, so that the shrimp can always live healthy. While other factors that are no less important that affect the success of shrimp ponds include;farming experience, area of land, stocking density of fry, amount of feed provided, number of workers/laborers used, capital, harvest time, and installation of windmills.

\subsubsection{Farming Experience}

There is also another opinion as stated by Jacobus and Palomba (2002: 7), someone wants to invest their capital in higher education, because they expect; (1) future acceptance is greater, (2). want to get satisfaction, and (3) want to increase their social status. Lately, experts are starting to become dissatisfied with only entering physical capital, because the non-physical capital contained in aquaculture farmers is no less important in increasing their production yields. The increase in aquaculture production was due to the use of new technologies such as; more efficient electric machines, windmills, fertilizers, and pest control, so skills are needed for these things through experience, education, training, counseling. The role of education, training, and counseling that can increase the knowledge of the skills of aquaculture farmers is not much different from physical capital. Therefore, expenditures for education, training, and extension are not consumption expenditures, but are investment expenditures.

\subsubsection{Land Area}

According to Soeratno (1986: 2.3), the production factors can basically be grouped into 4 main factors, namely; nature (land), labor, capital, and the ability to manage (managerial skills). The combination of these four factors will be able to produce production. The size of the use of production factors will affect the amount of production. Land is the main production factor for farmers in their field of business. According to Soekandar (2005: 32), arable land as a production factor in farming plays a very important basic role, because land can have dual functions, namely; As a place of business domicile; and as an absolute prerequisite so that other factors of production (labor, capital, and skills) can play a role.

If we compare the nature of the soil/land as a factor of pond production with other production factors, there will be some differences.First, the area of land used for expansion is essentially limited. This means that the area of land to increase fishery 
products is more limited than the addition of other production factors.Second, As a factor of production, land is more resistant than other factors of production. In other words, in production, pond land has a long element, because it does not experience depreciation (depreciation). While other production factors such as; mills, machines are shrinking.Third, the pond land cannot be moved/moved (no mobility), while other factors can be moved or moved.

\subsubsection{Stocking Density}

Shrimp seeds or fry (urang seeds) can come from catches in nature or from hatcheries in seed centers. Vannamei Shrimp Seeds, because they are introduced shrimp, come entirely from hatcheries in hatcheries. Even for producing Vannamei Shrimp seeds, most of the broodstock are still imported from America (Kordi, 2010). The stocking of the fry is done in the morning or evening after the weather is no longer hot, this is done to prevent the high mortality of the fry. To prevent high mortality from occurring, adaptation or acclimatization to the temperature and salinity of pond waters is carried out. The way to do fry acclimatization is the addition of seed transporting water with pond water gradually little by little, because temperature and salinity can cause failure at the time of stocking. The method of adapting the fry according to Rachmatun (1978) in Sunardi (2003) is that at first the transport water containing the fry is mixed with 1/5 of the pond water, an interval of 2-3 hours then added another $1 / 5$, and so on until the temperature is and salinity of the water according to pond water conditions. According to Kordi (2010), salinity is the concentration of the entire salt solution obtained in seawater. The increase in stocking density must be followed by an increase in the intensity of its management, especially feed and water quality. One of the important parameters of water quality in shrimp farming is dissolved oxygen consumed by shrimp for the respiration process.

\subsubsection{The amount of feed given}

Feed is a very important factor in the cultivation of Vannamei Shrimp because it absorbs 60-70\% of the total operational costs. Provision of appropriate feed will stimulate the growth and development of Vannamei Shrimp optimally so that its productivity can be increased. In principle, the denser the stocking of shrimp seeds means the less availability of natural food and the increasing dependence on artificial feed. Artificial feeding is based on the nature and eating behavior of Vannamei Shrimp (Nuhman, 2009). Vannamei shrimp have the nature of foraging during the day and night (diurnal and nocturnal) and are very voracious. These properties need to be known because they are related to the amount of feed and the frequency of feeding to be given. To make efficient use of feed, a system must be made that can make the feed optimally utilized entirely by shrimp. Provision of artificial feed in the form of pellets can be started from the time the fry are stocked until the shrimp are ready to harvest.

\subsubsection{Number of Labor/Labourers Devoted}

After land, the next very important production factor in the field of fisheries is labor. According to Harnanto (2009: 39), labor in farming can be divided into 3 types, namely: (a). human power, (b). animal/livestock labor, and (c). engine power. In economic theory; Animal and machine power are included in the capital factor, because animals and machines cannot double as managers. The marginal products of human labor and livestock labor follow a normal curve. This means that if the energy is used for a long period of time, initially it gives a marginal product which continues to increase to the maximum limit. After reaching the maximum limit then slowly continue to decrease. While the marginal product of engine power shows a constant marginal product as long as the engine can be used productively.

\subsubsection{Capital}

Capital plays a major role in the production process. According to Soeratno (2006 2.23) capital production factor is a very dominant factor in the production process. In an economic sense, capital can be interpreted as goods or money which together with the factors of production of land and labor can produce new goods, which in this case are of course the result of aquaculture. Then Sumodiningrat (2007: 1.13) states that capital is not a genuine factor of production, in the sense that it is not produced by nature, but is the result of a combination of natural factors and labor.

\subsubsection{Mill Installation}

ShrimpasAn artificial and closed aquatic ecosystem is in dire need of aquaculture technical treatment that can stimulate physical, chemical and biological processes towards the balance of the aquatic ecosystem. The balance of the pond aquatic ecosystem is expected to create a comfortable and safe environment for shrimp as in its natural ecosystem. One of the facilities that have a very important role in creating pond water conditions (especially in intensive shrimp culture) as mentioned above is a water wheel. A basic understanding of the role and function of the waterwheel in the operation of a shrimp pond is very necessary, so that the waterwheel can play an optimal role. Inadequate understanding of waterwheels will only function as accessories for a pond plot. 


\subsection{Operational Definition (Variable to be Researched)}

In general, some of the variables used and influencing this research are given operational limitations as follows;

1) Shrimp production is the number of shrimp produced by each farmer measured in kilograms per harvest season per hectare;

2) Business experience namely; experience of pond farmers doing business in the aquaculture sector (years);

3) The area of arable land is: the area of the pond used for shrimp rearing (ha);

4) The fry are; the number of seeds spread by farmers in their ponds (heads/ha);

5) Feed is; number of feedings to shrimp during cultivation (ha)

6) Labor is the outpouring of labor in the period of one harvest. In this case, both the workers of the farmers themselves, the workers of their family members, and the workers outside the family (others);

7) Capital, namely: all funds spent to obtain production results (per ha); and

8) Windmills are: tools used in aquaculture activities (units/ha);

\section{RESEARCH METHOD}

\subsection{PPopulation and Sample}

The population in this study were all pond farmers in Pidie Jaya Regency, namely: totaling 111 people. According to Serambi Indonesia (May 16: 2017) they have received business funding assistance from the central government. The sample was taken as much as $40 \%$ (45 respondents). From this number, 28 people with intensive farming patterns and 17 semi-intensive farming patterns were taken.

\subsection{Data analysis method}

After all the data collected will be analyzed through a quantitative analysis method approach. Based on the processing method, in this study the analysis of pond production is divided into two categories: intensively and semi-intensively.

The Cobb-Douglass function model for the analysis of this study takes the form:

$$
Y=\beta_{0} \cdot X_{1}^{\beta} X^{\beta 2} \cdot X_{3}^{\beta 3} \cdot X_{3}{ }^{\beta 4 . *} X_{3}^{\beta 5} X_{n}^{\beta 6} \cdot \mathcal{E}
$$

The transformation in linear form becomes:

$\operatorname{Ln} Y=\operatorname{Ln} \beta_{0}+\operatorname{Ln} X_{1}{ }^{\beta 1}+\operatorname{Ln} X^{\beta 2}+\operatorname{Ln} X_{3}{ }^{\beta 3 .}+\operatorname{Ln} X_{3}{ }^{\beta 4}+\operatorname{Ln} X_{3}{ }^{\beta 5}+\operatorname{Ln} X_{n}{ }^{\beta 6} .+\operatorname{Ln} \mathcal{E}$

Description:

$\mathrm{Y} \quad=$ production quantity $(\mathrm{kg})$

$\mathrm{X}_{1} \quad=$ labor experience (years)

$\mathrm{X} 2=$ area of arable land (ha).

$\mathrm{X}_{3} \quad=$ number of fry or stocking density (heads/ha)

$\mathrm{X}_{4} \quad=$ number of workers or uruh (person/ha)

$\mathrm{X}_{5} \quad=$ capital $(\mathrm{Rp} / \mathrm{ha})$

X6 = number of feeds given $(\mathrm{kg} / \mathrm{ha} / \mathrm{harvest}$ season $)$

$\mathrm{X}_{7} \quad=$ many mills $/ \mathrm{ha}$

$\beta_{0} \quad=$ constant

$\varepsilon=$ Error term

$\beta_{0} \ldots \ldots \beta_{7}=$ parameters.

For analysis as a whole (simultaneously) the Cobb-Douglass function model is modified to be of the form:

$$
\mathrm{Y}=\boldsymbol{\beta}_{0}+\boldsymbol{\beta}_{1} \mathrm{X}_{1}+\boldsymbol{\beta}_{2} \mathrm{X}_{2}+\boldsymbol{\beta}_{3} \mathrm{X}_{3}+\boldsymbol{\beta}_{4} \mathrm{X}_{4}+\boldsymbol{\beta}_{5} \mathrm{X}_{5}+\boldsymbol{\beta}_{6} \mathrm{X}_{6} \cdot+\mathcal{E}
$$

The modification of the model is due to the inclusion of the independent variable wheel which is considered qualitative. This variable is called a dummy variable (dummy variable). This dummy variable is given a value of 1 if they pair a pinwheel and is given a value of o if they do not use a pinwheel. To see the significance of the parameters sought, the t-test will be used.

\section{RESEARCH RESULTS AND DISCUSSION}

\subsection{Description of Research Object}

Based on the classification of age levels, the average age of respondents is 38.5 years, with a range between 21 to 70 years, that generally respondents are concentrated in the age of 41-50 years, namely $37.77 \%$, followed by ages between $31-40$ years with 
a percentage of $31,11 \%$. The third order with $15.56 \%$ is respondents who are more than 60 years old. Meanwhile, those aged between 21 - 30 years and those aged 51 - 60 were $8.89 \%$ and $8.89 \%$, respectively. In terms of the place of residence of the respondents, it turns out that $88.89 \%$ of them are natives in the village. Meanwhile, the other $11.11 \%$ were respondents from other regencies around Pidi Jaya, namely from the regencies of Pidie, Bireuen, and North Aceh.

The next classification is based on the period of education. The type of education in this case is divided into five categories: namely: non-formal education, basic education, junior high school education, high school education, university level education. For more details can be seen in Table 4.2. Most respondents (53.33\%) have a high school education background, there are even respondents who only have non-formal education, namely $4.44 \%$. While the background of basic education is only $8.88 \%$. The rest are junior high and college education backgrounds, respectively $15.56 \%$ and $17.77 \%$

Judging from the education period, the highest percentage is in the $10-11$ year interval class which covers $33.33 \%$ of all respondents. This means that they have been to the senior high school level, graduated or dropped out. The average education period of all respondents is around 11.32 years. Classification based on employment status, it turns out that 29 people (64.44\%) of the respondents whose main occupation is fish pond farmers, 7 people (15.56\%) work mainly as civil servants/ABRI, 6 people $(13.3 \%)$ as traders, and 2 people people $(13.33 \%)$ main occupation is private employee. While the rest is one person $(2.22 \%)$ of the respondents whose main job is a handyman.

Classification based on the number of family dependents. On average, they have family dependents (including the respondent themselves) of about 5 people. However, the highest frequency was found in the group of respondents with family dependents of 4-6 people (55.56\%). Then followed by respondents with family dependents 7 - 9 people (13.33\%), groups 1 - 3 people (22.22\%), and groups of $10-12$ people (8.88\%). In terms of the length of experience of respondents in Vannameii shrimp pond farming, the average is 3.8 years with a range of 1 year to 4 years. To make it easier to distinguish between each other.

The very high percentage of Vannameii Shrimp farming experience was 1 year, namely 11 people (33.33\%) and the lowest was those with 4 years experience, namely $8(17.77 \%)$. While those with 2 or 3 years of experience are 11 people (24.45\%). In terms of land use that is cultivated to produce production, the highest frequency is land use with an area interval of about $0.5-1$ Ha. In this interval, 8 people $(17.77 \%)$ of respondents had semi-intensive pond farming pattern and 21 people (46.67\%) respondents had intensive pond farming pattern.

The use of pond land with an area of $1.1-2 \mathrm{Ha}$ is the second largest in this study. At that interval, the number of semiintensive pond farmers was $5(11.11 \%)$ respondents and the number of intensive pond farmers was 7 (15.56\%) respondents. Utilization of the land area of $2.1-3 \mathrm{Ha}$ as many as 5 respondents. Three people $(6.67 \%)$ of them use a semi-intensive pond business pattern. Meanwhile, 2 people $(8.88 \%)$ are respondents who use intensive pond farming patterns. Apart from that, in this study there are also fishpond farmers who cultivate more than 3 hectares of land (= 5 hectares), namely: 1 person and the pattern used is an intensive pattern.

In terms of groups, the use of labor varies greatly in number. For pond entrepreneurs, the intensive pattern of using labor is 6 people with an area of 2.5 ha, only 1 respondent in this study. In more detail. Grouping in terms of frying by fishpond entrepreneurs is very dependent on the pattern of their business. For intensive Vannameii Shrimp farming business patterns, the number of fry ranges from 150,000 to $300,000 \mathrm{fish} /$ ha. The average calculation is 288,600 head per hectare. This number is higher than the semi-intensive pattern which only ranges from 120,000 to 150,000 per hectare. For semi-intensive farming patterns, the average stocking is 136,000 per hectare.

In terms of capital expenditure, the average capital expenditure for intensive pond business is Rp. 28,500,000/ha/harvest. This amount is very much different when compared to the costs incurred by semi-intensive pond entrepreneurs, namely the total production cost of Rp. 17,000. 000,-/ha/kalipanen. The next review is related to the provision of feed in the form of pellets. According to information, for entrepreneurs using a semi-intensive pattern, the amount of bait given for an area of 1 hectare ranges from 100 to $3,000 \mathrm{~kg}$ per harvest for an area of 1 hectare. However, for intensive pond farming, it ranges from 250 to $3,000 / \mathrm{kg} / \mathrm{rtime}$ of harvest. The final review is in terms of the use of the pinwheel. In this case, it turns out that there are not many variations, because for the semi-intensive pattern they do not use a mill.

\subsection{Research result}

\subsubsection{Classic assumption test}

Prior to the regression to see the effect of the independent variables on the dependent (independent) variable, the classical assumption was tested as a requirement for multiple linear regression, including tests for normality, multicollinearity, heteroscedasticity, and autocorrelation. Based on the results of the normality test, it can be seen that the dependent variable curve and the residual standard regression form a bell, meaning that the data is normal data. Furthermore, based on the results of the multicollinearity test, the VIF values of all independent variables are below 10, so the model is free from multicollinearity. The 
results of the heteroscedasticity test show that the plot spreads randomly above or below zero on the zero axis on the Regression Studentized Residual, so it is stated that there are no symptoms of heteroscedasticity. The results of the autocorrelation test are obtainedtable DW, obtained $\mathrm{dL}=1.019$ and $\mathrm{dU}=1.704$. The Durbin-Watson (DW) value is between $\mathrm{dU}(1.704)$ to $4-\mathrm{dU}$ (2.296), so there is autokeralcy, and the regression can be continued.

\subsection{2. - -t Uji test}

The $t$ test is a test used to see the effect partially (per variable) on the dependent variable. The independent variable in this study is said to be significant if $\mathrm{t}$ count $>\mathrm{t}$ table where the value of sig. $<0.05$. Based on SPSS processing obtained as listed in Table 1following.

Table 1 T-test

Coefficients

\begin{tabular}{|c|c|c|c|c|c|}
\hline \multirow[b]{2}{*}{ Model } & \multicolumn{2}{|c|}{ Unstandardized Coefficients } & \multirow{2}{*}{$\begin{array}{c}\text { Standardized } \\
\text { Coefficients }\end{array}$} & \multirow[b]{2}{*}{$\mathrm{t}$} & \multirow[b]{2}{*}{ Sig. } \\
\hline & B & Std. Error & & & \\
\hline 1 (Constant) & -134.331 & 117,635 & & -1.142 & .261 \\
\hline Experience & 289,448 & 50,272 & .651 & 5.758 & .000 \\
\hline Land area & 25,713 & 71,871 & .049 & .358 & .723 \\
\hline Labor & -6.510 & 52,912 & -.013 & -.123 & .903 \\
\hline Dense_Spread & .001 & .001 & .106 & .950 & .348 \\
\hline Number of Wheels & -4.040 & 8,967 & -.042 & -.451 & .655 \\
\hline Number_Pellet & .094 & .058 & .147 & 1,622 & .113 \\
\hline Capital & 8,216 & 5.311 & .194 & 1,547 & .130 \\
\hline
\end{tabular}

a. Bound Variable: Yield_Production

With a t-table of 2.02619, only one variable that affects production results is the experience variable because $t$ count $(5.758)>$ t table $(2.026)$ or sig. $(0.000)<0.05$

\subsubsection{Test- $F$}

The test used to see the effect of the independent variable on the dependent variable. If the independent variable has a simultaneous influence on the dependent variable, the regression equation model is included in the fit criteria. The regression equation includes fit criteria if $\mathrm{F}$ count $>\mathrm{F}$ table. The following can be seen the results of the SPSS output in Table 2

Table 2 F-test

\begin{tabular}{|ll|r|r|r|r|r|}
\hline Model & & ANOVA & Mean Square & F & Sig. \\
\hline 1 & Regression & Sum of Squares & df & M & 1223368.522 & 20.041 \\
& Residual & 8563579.655 & & $.000 \mathrm{~b}$ \\
& Total & 2258601456 & 37 & 61043.283 & \\
& 10822181.111 & 44 & & \\
\end{tabular}

a.Bound Variable:Production_Result

b. Predictors: (Constant), Capital, Number of Pellets, Number of Wheels, Manpower, Stocking Density, Experience, Land_Area

With F-table 2.277, it can be concluded that the regression equation is said to be fit because F-count (20.041) > F-table (2.277).

\subsection{Discussion}

In terms of the frequency of experience (X1), it turns out that this factor has a significant effect on increasing the production of Vannameii Shrimp farming production in the Pidie Jaya Regency. The influence of this factor cannot be separated from the existence of farming experience during tiger shrimp rearing activities. They have up to 20 years of experience in keeping tiger prawns. One of them is:Dahlan (42 years old) is a civil servant who also does pond farming in one of the shrimp ponds in Pidie Jaya.He stated that:

Potency Windu shrimp (Penaeus monodon) aquaculture was initially promising, especially for farmers in the East Coast of Aceh, because, apart from good shrimp fry (fry), the selling price of adult shrimp is also quite high. However, in recent years, due to lower selling prices and difficulty in obtaining good fry, it is difficult for farmers in the area to rebuild their shrimp aquaculture business. 
Another factor that also affects the failure of this shrimp aquaculture business, especially in Aceh, cannot be separated from the armed conflict that lasted for quite a long time, causing aquaculture activities to be disrupted. Indeed, not all of the ponds died completely, there are still one or two ponds that are still operating, however, the results obtained are still not sufficient. shrimp of another kind to fill in the pond." According to him, managing shrimp ponds can be said to be easy and difficult, the reason is quite simple, in addition to requiring serious maintenance, adequate capital is also needed. "If we want good results, we have to be willing to make sacrifices" he continued.

Dahlan has been in the shrimp aquaculture business for more than 20 years, although he is also part of the pond owner, he focuses more on the maintenance and development techniques of shrimp aquaculture. "Thank God, we did not feel the impact of the past conflict, maybe because we are in an urban environment, even though it is a bit close to the sea area, but the air is still urban." he said

At first, the business he initiated with a colleague from outside the City of Meureudu, like other ponds, was cultivating Tiger shrimp aquaculture, however, due to the difficulty of obtaining good fry, the aquaculture started cultivating aquaculture of the Vannamei type of shrimp (Litopenaeus Vannamei), which obtained from one of the shrimp farming companies in North Sumatra, "Indeed, the price is not as expensive as the price of Tiger shrimp, but with current conditions, we can benefit more from this type of shrimp."

Not only factors, good fry to determine the success of this shrimp aquaculture business, other factors that also influence is about maintenance, or maintenance techniques. With an incentive pattern of maintenance and care, it can be believed that the achievement of business profit targets can be maximized. Based on experience, Vannamei shrimp cultivation is not much different from tiger prawns or other types of shrimp, the most important thing is how we maintain water stability in the pond. Vannamei shrimp itself is classified as a shrimp that is easy to cultivate, because it is very tolerant of water density conditions, however it is better for us to be able to maintain the stability of the water density." Dahlan explained. Therefore, in general, Vannamei cultivation tends to only be carried out by middle to upper class entrepreneurs or farmers.

In order to avoid the spread of shrimp and shrimp seeds being cultivated by various diseases, there are several things that need to be considered, such as water, where the water to be added to the aquaculture ponds must be water whose quality has been improved through sedimentation plots and biofilters. This serves to prevent the entry of wild fish that have a tendency to carry disease. Meanwhile, to grow plankton in ponds that have been dried, prior to the filling and sowing process, fertilization is carried out using inorganic fertilizers (urea and TSP). Then, Bacillus sp probiotics were applied at a dose of 1 liter/plot.

This initial step is deemed necessary so that Vannamei shrimp aquaculture can produce as expected. Other steps that still need to be considered after filling the pond with fry are to carry out intensive monitoring of the density of the water. in the water in the pond." Then he continued, During maintenance, water management is also carried out which depends on fluctuations in water parameters such as organic matter, ammonia, nitrite, dissolved oxygen, $\mathrm{pH}$ and plankton.

In addition to the activities carried out in water management, it includes water changes, liming, water dilution as well as the application of fish biofilters and bioscreening. "But all of that will never mean anything, if we don't pay more attention to those who are workers, especially those who are constantly in the aquaculture area, such as those who are pond guards," he said.

Well...for him, maybe also his colleagues, giving freedom and attention to the employees who are the pond guards is the basic capital to achieve success in the business that has been involved for decades, in addition to requiring sufficient capital and expertise in managing an aquaculture. "It's not difficult to say, it's not easy to say, the most important thing is the determination to achieve maximum profit, so this is where we need sufficient capital, both materially and mentally." said Dahlan (Results of the interview 22 May 2017).

Factors related to the area of arable land (X2) did not have a positive effect on the production of Vannameii Shrimp in this research area. This is good for semi-intensive pond farming patterns and intensive pond farming patterns. Simultaneously, the cultivated area has not significantly affected the production of Vannameii Shrimp in the Pidie Jaya Regency. It is estimated that there is an influence on the level of fertility of the land which was once a former place for tiger prawns to be kept. This situation is in accordance with the opinion of Mubyarto (2009), which defines land as a factory where production results are produced, the level of production is highly dependent on the area of arable land and the level of fertility. The large influence of the area of arable land is understandable, because the land production factor is the dominant production factor in shrimp farming, even in all kinds of farming. Therefore, experts state that the area of arable land shows the size of the farm (farm size).

Then regarding the number of workers (X3) used as a whole, it has not been able to have much effect on increasing the production of Vannameii Shrimp in the research area. This factor is less influential because the productivity of the labor used is still in a low state, especially in semi-intensively managed ponds, where the workers come from their own families whose wages are sometimes rarely paid. In fact, proper payment of wages and a balanced distribution of results will be able to motivate the enthusiasm of the workers in a business field. 
Furthermore, regarding the number of fry (X4) that were spread in both semi-intensive and intensive farming patterns, it also did not show a positive effect on increasing production yields of Vannameii Shrimp pond farming in this research area. This situation means showing that; every addition of fry that is spread in the two types of pond business, it can be said that it has not had much effect in increasing the income of farmers. This is especially the case for semi-intensive farmers who spread shrimp above the maximum (300,000 head per hectare) which will result in the oxygen being needed by the fry not being met and the shrimp being in a non-uniform state, resulting in poorer quality. In general, in this research area, fry stocking is still looking for suitable conditions and some are still guided by the Windu shrimp fry stocking system, which is up to 300,000 tails per hectare. In fact, according to the rules, it is only allowed up to 250,000 head per hectare. Likewise for ponds that are managed semiintensively, are only allowed about 40,000 head per hectare to 150,000 head per hectare. However, in this study, it was also found that farmers spread their fry below the minimum limit which could result in a decrease in the yield obtained, because the quality of the shrimp was not good. Especially for intensive aquaculture farmers who almost spread the fry around 150,000 - 200,000 heads per hectare on average. In fact, according to the rules, it is only allowed up to 250,000 head per hectare. Likewise for ponds that are managed semi-intensively, are only allowed about 40,000 head per hectare to 150,000 head per hectare. However, in this study, it was also found that farmers spread their fry below the minimum limit which could result in a decrease in the yield obtained, because the quality of the shrimp was not good. Especially for intensive aquaculture farmers who almost spread the fry around 150,000 - 200,000 heads per hectare on average. In fact, according to the rules, it is only allowed up to 250,000 head per hectare. Likewise for ponds that are managed semi-intensively, are only allowed about 40,000 head per hectare to 150,000 head per hectare. However, in this study, it was also found that farmers spread their fry below the minimum limit which could result in a decrease in the yield obtained, because the quality of the shrimp was not good. Especially for intensive aquaculture farmers who almost spread the fry around 150,000 - 200,000 heads per hectare on average. However, in this study, it was also found that farmers spread their fry below the minimum limit which could result in a decrease in the yield obtained, because the quality of the shrimp was not good. Especially for intensive aquaculture farmers who almost spread the fry around 150,000 - 200,000 heads per hectare on average. However, in this study, it was also found that farmers spread their fry below the minimum limit which could result in a decrease in the yield obtained, because the quality of the shrimp was not good. Especially for intensive aquaculture farmers who almost spread the fry around 150,000 - 200,000 heads per hectare on average.

Regarding the installation of the mill (X5) in the farming activities of shrimp ponds in the research area, this has not significantly affected the production results obtained by the farmers. This is especially true for semi-intensive farming, because the stocking density exceeds the capacity of the land area, they install locks in an inadequate amount of oxygen required. As a result, shrimp life is not healthy. The unhealthy shrimp will decrease the production that will be obtained. In this situation, there is even a semi-intensive ushatani pattern that does not use a single unit of mill.

Furthermore, the number of feeds given (X6).In terms of feed, this type of shrimp is actually much cheaper when compared to the feed provided for Windu shrimp. Cheap does not mean different types of feed, but from the amount of use. Vannamei shrimp require feed with a protein content of 25-30\%, lower than tiger shrimp. In addition, the faster growth and higher survival rates, the production cost of Vannamei shrimp is $25-30 \%$ lower than the production cost of tiger prawns.

The bait given for the cultivation of Vannameii Shrimp in Pidie Jaya Regency so far is usually in the form of pellets with varying amounts by each fishpond farmer. For semi-intensive business patterns it ranges from 150-1,500 kg/hectare/spreading season, because they still depend on some natural bait. However, for intensive pond farming, the bait given is around 100,000$150,000 \mathrm{~kg} / \mathrm{hectare} / \mathrm{spreading}$ season. The regression results in this study also did not show a significant effect between the feed given by pond farmers in Vannameii Shrimp cultivation and the production results obtained in Pidie Jaya Regency. We can understand this that the Vannameii Shrimp aquaculture farmers in the area are still looking for compatibility with baiting for a certain number of stockings.

Finally, this research review concerns working capital (X7). The production factor of working capital plays a very important role in increasing the production of Vannameii Shrimp, both semi-intensive and intensive management. In semiintensive ponds, the capital spent is not too large, because they still depend on natural feeds. Apart from that, the use of windmills is not too much when compared to the intensive management pattern. In the intensive cultivation pattern, in addition to providing good bait and sufficient mill units, it is also necessary to maintain a guaranteed quantity and quality of water, use drugs, and various other activities related to the hope of increasing production yields. Regarding this business capital, respondents' responses were also drawn that;Vannamei shrimp production costs are lower, but still this shrimp culture, still cannot be applied to traditional and semi-intensive aquaculture, on the grounds that generally Vannamei cultivation in ponds uses intensive technology as a result of high stocking density, which can reach 100-300 fish/ m2. It also causes increased costs for construction, feed and other facilities. The results of data analysis relating to working capital can also be said to have not been significant in increasing the production of Vannameii shrimp pond farmers in Pidie Jaya Regency so far. 
International Journal of Research in Social Science and Humanities (IJRSS), Vol. 3 (2), Feb - 2022

\section{CONCLUSIONS AND SUGGESTIONS}

\subsection{Conclusion}

In the previous chapters, a description and analysis of the factors that influence the production of Vannameii Shrimp ponds in Pidie Jaya Regency has been presented, both semi-intensive and intensive management and based on theoretical and comparative considerations that are thought to influence it. From these various descriptions, with various limitations, it can be concluded, among others, as follows.

1) The experience factor has a significant effect on the $100 \%$ confidence level in increasing the production of ponds, both semiintensively and intensively managed.

2) Statistically at the $95 \%$ confidence level, it turns out that every additional 1 year of experience in Vannamei Shrimp farming activities will result in an increase in production yield of $651 \mathrm{~kg}$.

3) Factors such as the area of arable land, the number of workers employed, the density of fry stocked, the number of pinwheels installed, the amount of bait given, and the amount of capital spent statistically still have little effect on increasing the production of Vannamei Shrimp in Pidie Jaya district so far.

\subsection{Suggestions}

Based on the conclusions that have been stated above, on this occasion, in order to increase the production of Vannamei Shrimp farming in ponds in Pidie Jaya Regency, it is necessary to suggest, among others;

1) The area of the cultivated land must be adjusted to the density of the fry stocking done, because the spread of the fry outside a certain limit will result in the quality and quantity of shrimp being low;

2) The use of labor must really be considered, especially family workers need to be given encouraging incentives so that the spirit of working is more productive;

3) The use of the wheel must be taken into account so that the oxygen needed by the life of the Vannamei Shrimp does not experience a shortage;

4) For semi-intensive shrimp pond farmers, it is hoped that they should not rely too much on natural bait, because natural bait is not guaranteed for shrimp to grow well;

5) Capital has a very significant role, therefore capital assistance to Vannamei Shrimp pond farmers needs assistance from the government, among others; granting credit with soft interest, opening new land, and counseling on shrimp farming business for pond farmers.

\section{REFERENCES}

Andriyanto Fery, Anthon Efani, and Harsuko Riniwati, 2013. Analysis of Production Factors for Vannamei Shrimp (Litopenaeus Vannamei) Raising Business in Paciran District, Lamongan Regency, East Java; Cobb-Douglass Functional Approach, Lamongan.

Anggoro, S. 1983. The Problem of Water Fertility for Increasing Fish Production in Ponds. Faculty of Animal Husbandry, Diponegoro University, Semarang.

Arifianty, S. et al (2008). Optimization of Production Inputs for Vannamei Shrimp (Litopenaeus vannamei) at UD Jasa Produk Diri (JHD) Lamaran Tarung Village, Cantigi District, Indramayu Regency, West Java

Buckman, H.O. and N.C. Brady. 2002. Soil Science. (Soegiman Translation), Bhatara Karya Aksara, Jakarta.

Djurjani, 1998. Concept Mapping. PUSPICS-Faculty of Geography UGM. Yogyakarta.

Eddy, M. 1991. Wastewater Engineering: Treatment, Disposal and Reuse. Third Edition. . McGraw-Hill Publishing Co. New York.

Haliman, R. and Dian A. 2005. Vannameii Shrimp. Jakarta (ID): Penebar Swadaya.

Kordi, M. G. H. 2011. Smart Book of 32 Economical Marine Fish Cultivation. Yogyakarta (ID): Lily Publisher.

Soekandar, Wiraatmaja. 2005. Principles of Agricultural Extension, W. Jasaguna, Jakarta.

Soeratno. 2006. Agricultural Economics, Open University, UT. Jakarta. 